\title{
Decolourization of an azo dye in aqueous solution by ozonation in a semi-batch bubble column reactor
}

\author{
Che Zulzikrami Azner Abidin*, Muhammad Ridwan Fahmi, Ong Soon-An, \\ Siti Nurfatin Nadhirah Mohd Makhtar, Nazzery Rosmady Rahmat \\ School of Environmental Engineering, Universiti Malaysia Perlis (UniMAP), 02600 Arau, Perlis, Malaysia
}

*Corresponding author, e-mail: zulzikrami@unimap.edu.my

Received 25 Mar 2014

Accepted 13 Feb 2015

\begin{abstract}
The oxidative degradation of the azo dye Reactive Red 120 by ozonation was investigated. The decolourization was carried out by bubbling ozone at the bottom of a bubble column reactor containing the dye solution. The colour, chemical oxygen demand, and total organic carbon removal were evaluated, and the contaminants were characterized based on the changes in UV-Vis and FT-IR spectra. It was observed that changes of UV-Vis spectra represent the disappearance of both azo and aromatic groups, which causes the colour removal. FT-IR analysis indicated that ozonation shifts the functional groups in the azo dye which results in decolourization, a decrease in aromaticity, and an increase in acidity. The results indicate that the chromophore is destroyed and partially mineralized to small fragments during ozonation. The alkaline $\mathrm{pH}$ was favourable to decomposition by ozonation, initiated by the formation of the hydroxyl radicals. The oxidation followed first-order kinetics and the completed decolourization confirmed the capability of ozonation to cleave the azo bond from the dye.
\end{abstract}

KEYWORDS: chemical oxygen demand (COD), total organic carbon (TOC), decolourization kinetics

\section{INTRODUCTION}

Synthetic dyes have increasingly been used in the textile and other dyeing industries as they are easy and cheap to synthesize, generate greater colour variety than natural dyes, and are highly stable (i.e., resistant to light, temperature, and detergent) ${ }^{1-3}$. There are almost $700000 \mathrm{t}$ of approximately 10000 types of dyes and pigments produced annually worldwide, of which about $20 \%$ was assumed to be discharged from textile industries ${ }^{4}$. The azo dyes like Reactive Red 120 represents the largest and most important class, that accounted for over $50 \%$ of all commercial dyes ${ }^{5,6}$. Zollinger ${ }^{7}$ described the success of azo dyes is due to the simple synthesis procedure, great structural diversity, high molar extinction coefficient, and medium-to-high fastness properties to both light and wetness.

The release of these compounds into the environment is however undesirable because many azo dyes and their by-products are toxic and mutagenic $^{8,9}$. Even though the concentration of dyes in wastewaters is low, it often receives attention due to strong colour visible even at very low dye concentrations. Residual colours are difficult to remove completely by physical, chemical, or biological treatment processes. Moreover, the wastewater containing residual colour and compounds that are not easily biodegradable may cause environmental concerns and aesthetically displease ${ }^{10}$. Without sufficient treatment, dyes are stable and persist in the environment for an extended period.

The treatment of dye-containing wastewater poses considerable problems to the wastewater treatment industry. Treatments using physical, chemical, and biological procedures or its combinations are well established methods for colour removal $^{11}$. Conventional physical or chemical treatment methods such as coagulation, flocculation, filtration, adsorption, ion exchange or ultra-filtration, although efficient, often produce sludge or solid waste which requires further disposal ${ }^{12-15}$. Biological treatment systems are often inefficient due to low biodegradability of dyes ${ }^{13}$.

The chemical oxidation treatments involves the use of oxidants such as ozone, hydrogen peroxide, permanganate, chlorine, and oxygen, to change the chemical composition of a compound or a group of compounds such as dyes ${ }^{16}$. Among these oxidants, ozone is the most widely used as it is highly reactive and it can remove colour efficiently ${ }^{17}$. In a process called selective oxidation, ozonation can effectively decolourize the wastewater by breaking the conjugated azo bonds associated with the 
dye ${ }^{15,18}$. In principle, ozonation should be able to oxidize inorganic substances to their highest stable oxidation states and organic compounds to $\mathrm{CO}_{2}$ and water ${ }^{14,19}$. Ozonation cleaves the conjugated bonds of azo dye chromophores, groups which are responsible for the colour of the dye, leading to colour removal and enhancing biodegradability ${ }^{20-23}$. The ozonation has excellent potential for dye-containing wastewater removal as it does not generate sludge or solid wastes, decolourization occurs simultaneous with degradation reducing operational costs $15,24,25$. Ozonation is effective in reducing the colour of the dye-containing wastewater, but not so effective in reducing the chemical oxygen demand (COD) and total organic carbon (TOC) ${ }^{26}$.

Despite the excellent potential of ozonation, most studies have focused on the decolourization rather than COD and TOC reduction. Thus the aim of this study was to show that ozonation is effective in reducing COD and TOC as well as decolourization of azo dye (Reactive Red 120).

\section{MATERIALS AND METHODS}

\section{Solutions}

Reactive Red $120\left(\mathrm{C}_{44} \mathrm{H}_{30} \mathrm{Cl}_{2} \mathrm{~N}_{14} \mathrm{O}_{20} \mathrm{~S}_{6}\right.$, Fig. 1) was of analytical grade obtained from Sigma-Aldrich, and used without further purification. A $10 \mathrm{~g} / \mathrm{l}$ stock solution was used to prepare a $0.5 \mathrm{~g} / 1$ dye concentrations by dilution. The $\mathrm{pH}$ of aqueous solutions was adjusted using either $0.1 \mathrm{~N} \mathrm{NaOH}$ or $0.1 \mathrm{~N} \mathrm{HCl}$ to raise or to lower the $\mathrm{pH}$ upon decolourization and degradation. All solutions were prepared using distilled water.

\section{Methods}

The schematic diagram of the bench-scale reactor system shown in Fig. 2 consists of an oxygen cylinder, ozone generator, glass reactor, and KI reactor. Ozone was generated from an A2ZZ-3G ozone generator utilizing $99.5 \%$ oxygen gas introduced at a rate of $3 \mathrm{l} / \mathrm{min}$. Ozone applications were carried out in a cylindrical glass reactor $(450 \mathrm{~mm} \times 85 \mathrm{~mm}$

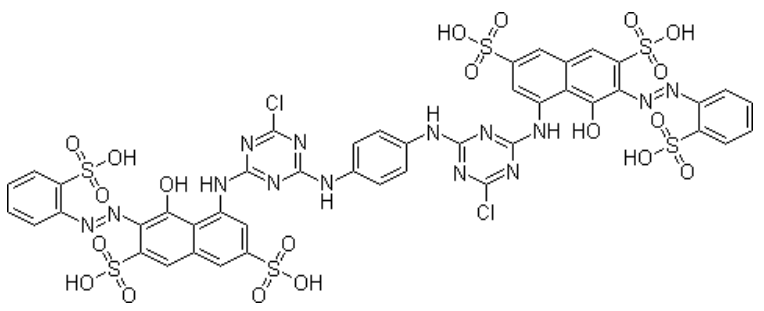

Fig. 1 General chemical structure of reactive Red 120 .

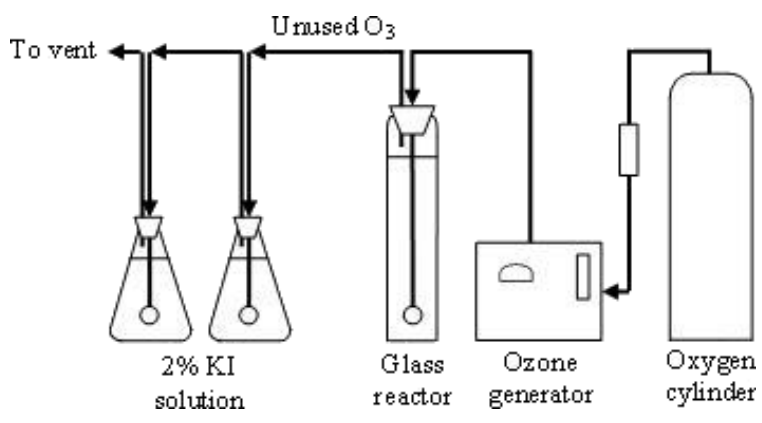

Fig. 2 Schematic diagram of the bench-scale reactor system.

ID) of the $2000 \mathrm{~m}$ working volume. The dye solution with the concentration of $0.5 \mathrm{~g} / 1$ was injected through a diffuser at a flow rate of $10.2 \mathrm{mg} / \mathrm{min}$, followed by 5 min aeration to remove residual ozone. All connections from the ozone generator to the reactor were made through Teflon tubing. Samples were taken from the reactor every 5 min during ozonation, and the total time for each experiment was $40 \mathrm{~min}$. The excess ozone, leaving the reactor was decomposed through a glass reactor filled with $2000 \mathrm{~m}$ of $2 \% \mathrm{KI}$ solution. The experiments were conducted at room temperature, and samples were withdrawn at definite time intervals for determination of colour, COD, TOC, UV-Vis, and FT-IR spectra analysis.

\section{Analytical methods}

The ozone flow rate in feed gas was determined by the KI-starch titration method ${ }^{26}$. The decolourization and degradation were determined by measurements of absorbance at wavelengths ranging from $200-800 \mathrm{~nm}$ by a Hitachi UV-Vis U-2810 spectrophotometer. The maximum visible region $\left(\lambda_{\max }\right.$ $535 \mathrm{~nm}$ ) was employed as a base to follow the Reactive Red 120 decolourization, using a $10 \mathrm{~mm}$ quartz cell. The $\mathrm{pH}$ was measured by Hanna Instruments HI223 pH meter. COD was determined in accordance with the closed reflux, calorimetric method ${ }^{27}$. The TOC was analysed using commercially available test kits (HACH Direct method, 10173) in a 15$150 \mathrm{mg} / \mathrm{l}$ concentration range ${ }^{28}$. The evolution in functional groups of the dye samples was analysed using PerkinElmer Spectrum 400 FT-IR spectrophotometer over the range of $4000-400 \mathrm{~cm}^{-1}$. However, the dye samples were evaporated at $65^{\circ} \mathrm{C}$, to remove water completely from the samples prior to FTIR analysis. The characteristics of dye-containing wastewater are shown in Table 1. 
Table 1 Characteristics of dye-containing wastewater.

\begin{tabular}{lc}
\hline Initial dye concentration & $500 \mathrm{mg} / 1$ \\
$\mathrm{pH}$ & 5.6 \\
$\lambda_{\max }$ & $535 \mathrm{~nm}$ \\
$\mathrm{COD}$ & $264.0 \mathrm{mg} / 1$ \\
TOC & $98.0 \mathrm{mg} / 1$ \\
\hline
\end{tabular}

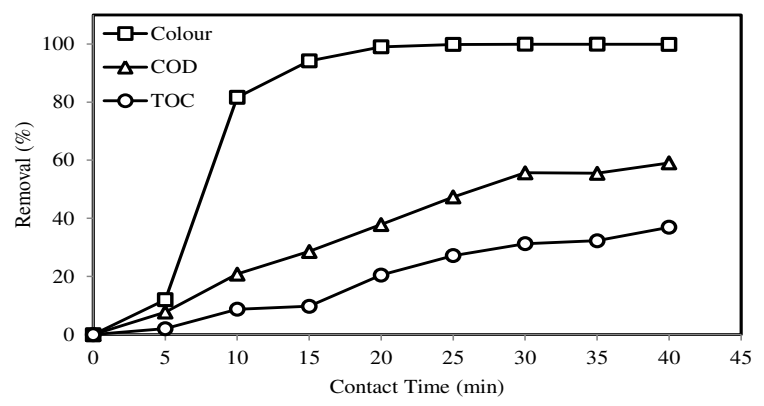

Fig. 3 Removal of colour, COD and TOC during ozonation at different contact times.

\section{RESULTS AND DISCUSSION}

\section{Effects of ozonation on colour, COD, and TOC removal}

Fig. 3 shows the colour, COD, and TOC removal percentages of Reactive Red 120 at an initial dye concentration of $0.5 \mathrm{~g} / 1$ during ozonation. The $\mathrm{pH}$ of the dye-laden synthetic wastewater was adjusted to $\mathrm{pH} 7$ prior to ozonation using a $0.1 \mathrm{~N} \mathrm{NaOH}$ solution. The ozonation was evaluated at $5,10,15$, $20,25,30,35$, and $40 \mathrm{~min}$. For a given time, an increase in contact time has resulted in an increase in colour, COD, and TOC removal. During the first $5 \mathrm{~min}$, there were no significant changes in colour, COD, or TOC removal, but after 40 min they reached nearly $100 \%, 60 \%$, and $37 \%$, respectively. The colour removal occurred faster than COD and TOC removal, indicating that the chromophore may have been destroyed during ozonation and partially mineralized to small fragments. Complete decolourization confirmed the capability of ozone to cleave the azo bond from the Reactive Red 120. However, limited COD and TOC removal could be explained by incomplete oxidation of organic materials and production of small organic molecular fragment along with the destruction of the dye-containing wastewater not being completely oxidized ${ }^{29}$.

The COD removal was more efficient than TOC removal throughout the ozonation experiments. These results may suggest that small organic molecular fragments resulting from the destruction of the dyes are not completely oxidized to $\mathrm{CO}_{2}$ and wa-

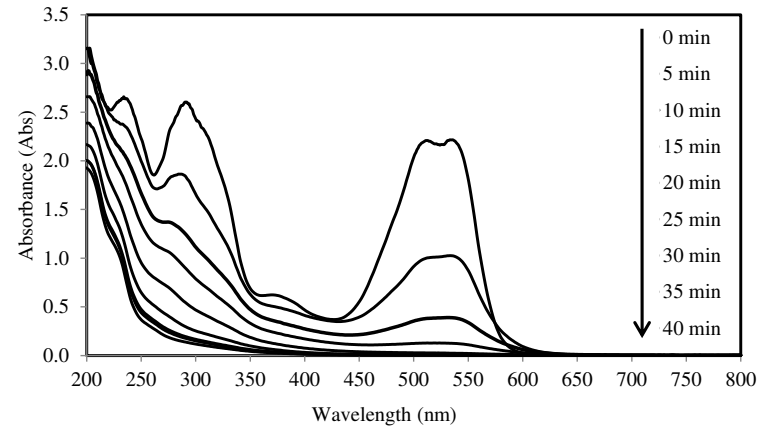

Fig. 4 Changes of UV-Vis spectra during ozonation at different contact times.

ter ${ }^{12}$. The drop in TOC values may suggest that $\mathrm{CO}_{2}$ molecules are formed simultaneously with other volatile organic compounds such as formaldehyde and acetaldehyde during the ozonation ${ }^{30}$. Ozonation of Bomaplex Red CR-L dye of an initial concentration of $1 \mathrm{~g} / 1$ approximately results in a 54\% COD removal ${ }^{25}$, while ozonation of dyes generally leads to small organic molecular fragments, such as acetic acids, aldehydes, and ketones that result in a residual $\mathrm{COD}^{31}$. COD resulting from these small newly formed molecules can therefore be further degraded by biological treatment. During the removal of the reactive dye Procion Red MX-5B, COD removal was better than TOC under identical operating conditions of $0.25 \mathrm{~g} / 1$ and $30 \mathrm{~min}$ ozonation ${ }^{12}$, similar results were also reported during 120 min ozonation of Reactive Orange 13 dye $^{23}$.

\section{UV-Vis spectra analysis}

The changes of UV-Vis spectra during ozonation at different contact times are shown in Fig. 4. The reduction in absorbance in the visible region indicated the decolourization through cleavage of the chromophore, which in azo dyes is characterized by the $\mathrm{N}=\mathrm{N}$ bond. The chromophore containing the azo bond has absorption in the visible region, while benzene and naphthalene rings in the UV region. Moreover, the naphthalene ring absorption wavelength is higher than that of benzene rings ${ }^{32}$. The spectrum of the initial solution presents the characteristics of the azo bond which causes the colour at $535 \mathrm{~nm}$ and the benzene and naphthalene rings bonded to the azo bond at 220 and $322 \mathrm{~nm}$, respectively. The intensity of absorption of the azo bond declined rapidly as the ozonation time proceeded. The subsequent ozonation causes continuous decrease of UV band intensities and rapid disappearance of the visible band without the 


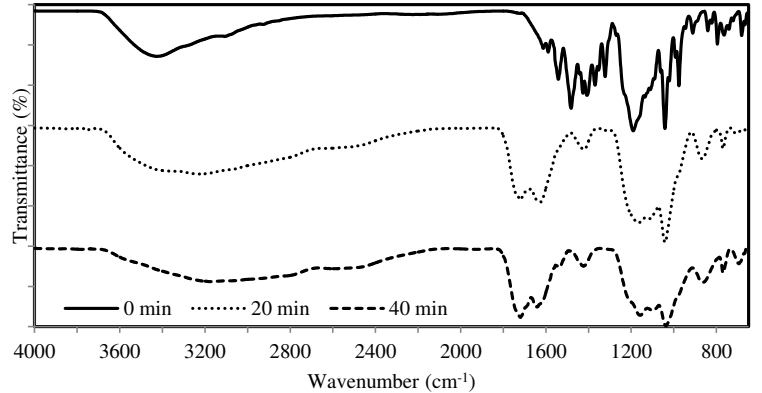

Fig. 5 Changes of FT-IR spectra during ozonation at different contact times.

appearance of new absorption bands in the UV-Vis region. The dramatic changes of UV-Vis spectra represent disappearance of both azo and aromatic groups, resulting in the decolourization and suggesting the sensitivity of the oxidized dye molecule towards ozonation.

\section{FT-IR spectra analysis}

Fig. 5 shows the FT-IR spectra of Reactive Red 120 during ozonation time of 0,20 , and $40 \mathrm{~min}$. The majority of the absorption peaks present prior to ozonation either shifted or disappeared. The peak intensities characteristic of the azo bond (at $1500 \mathrm{~cm}^{-1}$ ) and the benzene ring (at $1600-1400 \mathrm{~cm}^{-1}$ ) decreased with time. These results indicated that it may be oxidized with the disappearance of both the parental dyes and their primary aromatic breakdown products. The peaks located at $1180 \mathrm{~cm}^{-1}$ may be due to a sulphonate group, which almost disappeared after ozonation. This indicates the mineralization of the sulphonate group during ozonation. The new absorption peak at $1700-1600 \mathrm{~cm}^{-1}$ appearing after $40 \mathrm{~min}$ ozonation is the characteristic of $\mathrm{C}=\mathrm{C}$ that may be formed from alkenes, while the peak observed after ozonation in $3300-2500 \mathrm{~cm}^{-1}$ may be attributed to carboxylic acids ${ }^{33}$. The intensities of these absorption peaks increased with time, indicating that some carboxylic acids were formed during the degradation. The above observations indicate that the sulphonic acid groups of the dye may be substituted by hydroxyl groups followed by oxidation and cleavage of the naphthalene ring with the formation of low molecular weight carboxylic acids ${ }^{12}$. Based on the peaks obtained, azo groups are detected in the initial sample, and disappeared after ozonation. The result indicated that ozonation shifted the functional groups in azo dye which result on decolourization and decrease in aromaticity of Reactive Red 120.

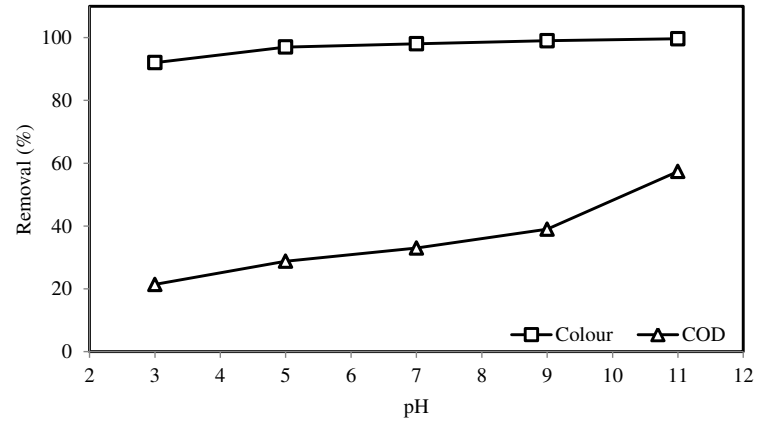

Fig. 6 Effect of $\mathrm{pH}$ on decolourization and COD removal at different $\mathrm{pH}$.

\section{Effects of $\mathrm{pH}$}

Ozonation was performed for $20 \mathrm{~min}$ at different $\mathrm{pH}$ of 3, 5, 7, 9, 11 and the data is presented in Fig. 6 . Increase in colour and COD removal were observed as the $\mathrm{pH}$ was increased from acidic to alkaline range indicating that the alkaline $\mathrm{pH}$ is favourable for decomposition by ozonation which is initiated by the formation of the hydroxyl radicals at higher $\mathrm{pH}$ values $^{20,21,34}$. At $\mathrm{pH} 11$, colour and COD removal observed were $100 \%$ and $58 \%$, respectively. The ozonation pathways are either due to direct oxidation by molecular ozone, or indirect oxidation by hydroxyl radicals with oxidants in acidic solution is molecular ozone, while in neutral and basic solution it is the hydroxyl radicals ${ }^{3}$. Hence direct oxidation is slower than indirect oxidation since the oxidation potential of hydroxyl radicals is higher than that of the ozone molecule.

\section{Decolourization kinetics}

The kinetics of the ozonation plays an important role in assessing the efficiency and feasibility of treating dye-containing wastewater. When the amount of ozone is in excess or when the ozone concentration is assumed to reach a stationary stage at the interface, the oxidation rate follows pseudo-first-order kinetics with respect to the concentration of the organic substances ${ }^{31}$. The decolourization kinetics was evaluated by plotting $\ln \left(C_{t} / C_{0}\right)$ values versus reaction time following a first-order kinetics:

$$
C_{t}=C_{0} \exp \left(-k_{\mathrm{d}} t\right)
$$

where $C_{t}, C_{0}$ are, respectively, the dye concentration after an ozonation time $t$ and the dye initial concentration; while $k_{\mathrm{d}}$ stands for the first-order reaction rate constant. The kinetics experiment was conducted with the initial concentration fixed at $100 \mathrm{mg} / \mathrm{l}$ and an initial $\mathrm{pH}$ of 7 . Fig. 7 shows that 


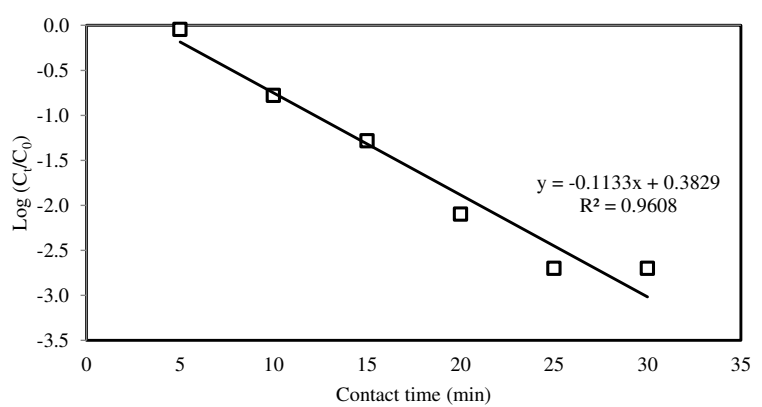

Fig. 7 Decolourization kinetics of ozonation at different contact times.

the curve was well fitted to first-order kinetics, and the square of the relative correlation coefficient, $R^{2}$ of experimental results was higher than 0.96 . The slope of the linear curve represents the first-order rate constant and was about $0.113 / \mathrm{min}$. Similar results were also reported that the slope of the linear curve represents the first-order rate constant and was about $1.09 / \mathrm{min}^{31}$. The same first-order types of behaviour were also reported elsewhere ${ }^{35,36}$.

\section{CONCLUSIONS}

In the present study, the performance of ozonation for colour, COD and TOC removal of azo dye Reactive Red 120 dye were evaluated and found to be an efficient technique for wastewater treatment. The colour removal efficiency of over $98 \%$ was obtained at contact time of $30 \mathrm{~min}$, thus emphasizes that ozonation is a very efficient process for colour removal. Moreover, the limited COD and TOC removal obtained emphasize that COD removal was more efficient than TOC removal throughout the ozonation. The dramatic changes of UV-Vis spectra represent the disappearance of both azo and aromatic groups, resulting in the decolourization of the dye sample and suggesting the sensitivity of the oxidized dye molecule towards ozonation. While the FT-IR analysis indicated that ozonation shifted functional groups in azo dye which results in decolourization and decrease in aromaticity. The increase of $\mathrm{pH}$ from acidic to alkaline range would increase the colour and COD removal. Those results indicated that chromophore was destroyed during ozonation and partially mineralized to small fragments. Complete decolourization confirms the capability of ozonation to cleave the azo bond from the Reactive Red 120. Hence the application of ozonation as pre-treatment for biological treatment may further mineralized the dye-containing wastewater.
Acknowledgements: The authors thank the Ministry of Higher Education, Malaysia for financial support (FRGS 9003-00282).

\section{REFERENCES}

1. Rodríguez Couto S (2009) Dye removal by immobilised fungi. Biotechnol Adv 27, 227-35.

2. Mahdavi Talarposhti A, Donnelly T, Anderson GK (2001) Colour removal from a simulated dye wastewater using a two-phase anaerobic packed bed reactor. Water Res 35, 425-32.

3. Özer A, Akkaya G, Turabik M (2006) The removal of Acid Red 274 from wastewater: Combined biosorption and biocoagulation with Spirogyra rhizopus. Dyes Pigments 71, 83-9.

4. Muhammad A, Shafeeq A, Butt MA, Rizvi ZH, Chughtai MA, Rehman S (2008) Decolorization and removal of COD and BOD from raw and biotreat textile dye bath effluent through advanced oxidation processes (AOPs). Braz J Chem Eng 25, 453-9.

5. Hunger K (2003) Industrial Dyes: Chemistry, Properties, Applications, Wiley-VCH, Germany.

6. Chung YC, Chen CY (2008) Degradation of azo dye reactive violet 5 by $\mathrm{TiO}_{2}$ photocatalysis. Environ Chem Lett 7, 347-52.

7. Zollinger H (2003) Color Chemistry-Syntheses, Properties, and Applications of Organic Dyes and Pigments, Wiley-VCH, German.

8. Wang A, Qu J, Ru J, Liu H, Ge J (2005) Mineralization of an azo dye acid red 14 by electro-Fenton's reagent using an activated carbon fiber cathode. Dyes Pigments 65, 227-33.

9. Guelli Ulson de Souza SMA, Santos Bonilla KA, Ulson de Souza AA (2010) Removal of COD and color from hydrolyzed textile azo dye by combined ozonation and biological treatment. $J$ Hazard Mater 179, 35-42.

10. Hsing HJ, Chiang PC, Chang EE, Chen MY (2007) The decolorization and mineralization of Acid Orange 6 azo dye in aqueous solution by advanced oxidation processes: A comparative study. $J$ Hazard Mater 141, 8-16.

11. Anjaneyulu Y, Sreedhara Chary N, Samuel Suman Raj D (2005) Decolourization of industrial effluents - available methods and emerging technologies - a review. Rev Environ Sci Bio Tech 4, 245-73.

12. Pachhade K, Sandhya S, Swaminathan K (2009) Ozonation of reactive dye, Procion red MX-5B catalyzed by metal ions. J Hazard Mater 167, 313-8.

13. Fu Y, Viraraghavan T (2001) Fungal decolorization of dye wastewaters: a review. Bioresour Tech 79, 251-62.

14. Shu HY, Chang MC (2005) Decolorization effects of six azo dyes by $\mathrm{O}_{3}, \mathrm{UV} / \mathrm{O}_{3}$ and $\mathrm{UV} / \mathrm{H}_{2} \mathrm{O}_{2}$ processes. Dyes Pigments 65, 25-31.

15. Srinivasan SV, Rema T, Chitra K, Sri Balakameswari 
K, Suthanthararajan R, Uma Maheswari B, Ravindranath E, Rajamani S (2009) Decolourisation of leather dye by ozonation. Desalination 235, 88-92.

16. Metcalf Eddy Inc (2003) Wastewater Engineering: Treatment and Reuse. McGraw-Hill, 4th edn, New York.

17. Alaton IA, Balcioglu IA, Bahnemann DW (2002) Advanced oxidation of a reactive dyebath effluent: comparison of $\mathrm{O}_{3}, \mathrm{H}_{2} \mathrm{O}_{2} / \mathrm{UV}-\mathrm{C}$ and $\mathrm{TiO}_{2} / \mathrm{UV}$-A processes. Water Res 36, 1143-54.

18. Gomes AC, Fernandes LR, Simões RMS (2012) Oxidation rates of two textile dyes by ozone: Effect of $\mathrm{pH}$ and competitive kinetics. Chem Eng $J$ 189-190, 175-81.

19. Glaze WH, Kang JW, Chapin DH (1987) The chemistry of water treatment processes involving ozone, hydrogen peroxide and ultraviolet radiation. Ozone Sci Eng 9, 335-52.

20. Selcuk H (2005) Decolorization and detoxification of textile wastewater by ozonation and coagulation processes. Dyes Pigments 64, 217-22.

21. Zhang F, Yediler A, Liang X, Kettrup A (2004) Effects of dye additives on the ozonation process and oxidation by-products: a comparative study using hydrolyzed C.I. Reactive Red 120. Dyes Pigments 60, $1-7$.

22. Lackey LW, Mines Jr RO, McCreanor PT (2006) Ozonation of acid yellow 17 dye in a semi-batch bubble column. J Hazard Mater B138, 357-62.

23. Gutowska A, Kałużna-Czaplińska J, Jóźwiak WK (2007) Degradation mechanism of Reactive Orange 113 dye by $\mathrm{H}_{2} \mathrm{O}_{2} / \mathrm{Fe}^{2+}$ and ozone in aqueous solution. Dyes Pigments 74, 41-6.

24. Muthukumar M, Sargunamani D, Selvakumar N (2005) Statistical analysis of the effect of aromatic, azo and sulphonic acid groups on decolouration of acid dye effluents using advanced oxidation processes. Dyes Pigments 65, 151-8.

25. Oguz E, Keskinler B, Çelik Z (2005) Ozonation of aqueous Bomaplex Red CR-L dye in a semi-batch reactor. Dyes Pigments 64, 101-8.

26. Sarasa J, Roche MP, Ormad MP, Gimeno E, Puig A, Ovelleiro JL (1998) Treatment of a wastewater resulting from dyes manufacturing with ozone and chemical coagulation. Water Res 32, 2721-7.

27. APHA-AWWA-WEF (2005) Standard Methods for the Examination of Water and Wastewater, 21st edn, APHA, Washington, DC.

28. Martínez SS, Bahena CL (2009) Chlorbromuron urea herbicide removal by electro-Fenton reaction in aqueous effluents. Water Res 43, 33-40.

29. Al-Kdasi A, Idris A, Saed K, Guan CT (2004) Treatment of textile wastewater by advanced oxidation processes - a review. Global NEST Int J 6, 222-30.

30. Koch M, Yediler A, Lienert D, Insel G, Kettrup A (2002) Ozonation of hydrolyzed azo dye reactive yellow 84 (CI). Chemosphere 46, 109-13.
31. Khadhraoui M, Trabelsi H, Ksibi M, Bouguerra S, Elleuch B (2009) Discoloration and detoxicification of a Congo red dye solution by means of ozone treatment for a possible water reuse. J Hazard Mater 161, 974-81.

32. Feng W, Nansheng D, Helin H (2000) Degradation mechanism of azo dye C. I. reactive red 2 by iron powder reduction and photooxidation in aqueous solutions. Chemosphere 41, 1233-8.

33. Brown WH, Foote CS, Iverson BL (2005) Organic Chemistry, Thomson Learning, Inc.

34. Rajeswari R, Kanmani S (2010) Comparative study of photocatalytic oxidation and photolytic ozonation for the degradation of pesticide wastewaters. Desalin Water Treat 19, 301-6.

35. Wu J, Wang T (2001) Ozonation of aqueous azo dye in a semi-batch reactor. Water Res 35, 1093-9.

36. Shu HY, Huang CR (1995) Degradation of commercial azo dyes in water using ozonation and UV enhanced ozonation process. Chemosphere 31, 3813-25. 